\title{
Morphological and morphometric comparisons of the first zoea of four species of purse crabs (Decapoda: Brachyura: Leucosiidae) from the Brazilian South Atlantic
}

\author{
GUSTAVO L. HIROSE ${ }^{1,2,3}$, RAFAEL A. GREGATI ${ }^{2}$, ADILSON FRANSOZO ${ }^{2}$ \\ \& MARIA L. NEGREIROS-FRANSOZO ${ }^{2}$ \\ ${ }^{1}$ Laboratório de Carcinologia, Departamento de Biologia, Centro de Ciências Biológicas e da Saúde, Universidade Federal de Ser- \\ gipe (UFS) Cidade Universitária Prof. José Aloísio de Campos, Av. Marechal Rondon, s/n, Jardim Rosa Elze, 49100-000 São Cris- \\ tóvão, Sergipe, Brazil \\ ${ }^{2}$ NEBECC (Study Group of Crustacean Biology, Ecology and Culture), Departamento de Zoologia, Instituto de Biociências, Universi- \\ dade Estadual Paulista (UNESP), 18618-000 Botucatu, São Paulo, Brazil \\ E-mail: gustavo_lh@hotmail.com \\ ${ }^{3}$ Corresponging author
}

\begin{abstract}
Morphological descriptions of the first larval stages of Persephona mediterranea, P. lichtensteinii and P. punctata (Leucosiidae: Eballinae) from the South Atlantic are provided, with comparisons among the morphometry of the species. A detailed description and eight morphometric measurements were made for each larva, and a discriminant function analysis was used to interpret the data set. The species differed significantly in certain morphological and morphometric features. These characteristics may help in the identification of species of Leucosioidea found in the South Atlantic, and can be an important tool in ecological studies, supporting the identification of planktonic morphotypes at the species level.
\end{abstract}

Key words: Persephona; larval description, larval morphometry

\section{Introduction}

Members of the superfamily Leucosioidea Samouelle, 1819, are commonly known as purse crabs. These crabs live in subtidal marine environments, mainly inhabiting sandy bottoms of coastal regions, although some species can be found at depths up to $400 \mathrm{~m}$ (Melo 1996). The superfamily comprises two families: Iphiculidae Alcock, 1896, and Leucosiidae Samouelle, 1819, with three subfamilies, Cryptocneminae, Ebaliinae and Leucosiinae. Only the subfamily Ebaliinae (formed by grouping subfamilies Ebaliinae, Philyrinae, and Iliinae) ( $\mathrm{Ng}$ et al. 2008) occurs throughout the Atlantic Ocean. Persephona Leach, 1817, is one of the most common genera of purse crabs in Brazil, with four species: Persephona crinita Rathbun, 1931; P. lichtensteinii Leach, 1817; P. mediterranea (Herbst, 1794); and P. punctata (Linnaeus, 1758) (Melo 1996).

Larvae of several leucosiid genera have been described as follows: three species of Arcania Leach, 1817: A. septemspinosa (Fabricius, 1793), by Sankolli (1961), A. undecimspinosa De Haan, 1841, by Terada $(1979,1984)$ and Quintana (1984, 1986a, 1986b), and A. undecimspinosa elongata Yokoya, 1933, by Terada (1984); six species of Ebalia Leach, 1817: E. cranchii Leach, 1817, by Lebour (1928, 1982), E. nux A. Milne Edwards, 1883, by Rice (1980b), E. rotundata A. Milne Edwards, 1880 (described as Lithadia rotundata) by Fransozo \& Bertini (2002), E. tuberosa (Pennant, 1777), by Lebour (1928) and Salman (1982), E. tumefacta (Montagu, 1808), by Salman (1982), and an unidentified species by Aikawa (1929); one species each of Ilia Leach, 1817and Ixa Leach, 1815: Ilia nucleus (L., 1758), by Heegaard (1963) and Bartilotti et al. (2009) and I. cylindrus (Fabricius, 1777), by RajaBai (1960); six species of Leucosia Bell, 1855: L. anatum (Herbst, 1783), by Terada (1984), L. biannulata Tyndale-Biscoe \& George, 1962, by Ghory \& Siddiqui (2008), L. cranicolaris (Herbst, 1783), by Quitana (1984, 1986a, 1986b), L. longifrons De Haan, 1841, by Terada (1979), L. obtusifrons De Haan, 1841, by Terada (1984), and $L$. 